To cite this article: Dario Banegas, Anahí Pavese , Aurelia Velázquez \& Sandra María Vélez (2013): Teacher professional development through collaborative action research: impact on foreign English language teaching and learning, Educational Action Research, 21:2, 185-201 To link to this article: http://dx.doi.org/10.1080/09650792.2013.789717

\title{
Teacher professional development through collaborative action research: impact on foreign English language teaching and learning
}

\begin{abstract}
In 2011, we, a group of English as a foreign language teachers at a secondary school in Argentina, decided to investigate our teaching practices through collaborative action research so as to improve our students' learning opportunities and thus revitalise English Language Teaching in our context. We implemented and evaluated the integration of content and language learning in our classrooms through the development of our own materials. The experience revealed a growth in professional development and how our motivation and autonomy influenced our students' motivation and language development. In our attempt to disseminate our experience as a group, this report particularly focuses on the evaluation facets of our CAR project so as to encourage other teachers and teacherresearchers to adopt CAR to improve their own practices.
\end{abstract}

Key words: collaborative action research, ELT, CLIL.

\section{Introduction}

In 2011, we, a group of English as a foreign language (EFL) teachers at a secondary school in Argentina, decided to investigate our teaching practices as we felt that we needed to revitalise ELT (English Language Teaching) in our context. For around ten years, we had collaboratively planned our EFL lessons and courses and agreed on strategies, a macro framework of reference in which our practices could be inscribed, and coursebooks. Equally, we had individually and non-systematically planned lessons which integrated content and foreign language learning to meet the demands of those students whose command of English was higher than that suggested by the official curriculum. Yet, we were aware that demotivation among our students was affecting teaching and learning. 
As the number of teenage students who attended English private lessons began to increase, their demands for 'something more than the coursebook' and decreasing motivation suggested that we had to revisit our practices and syllabi and offer a different approach. Because we sought to explore Content and Language Integrated Learning (CLIL) by investigating and acting on our own practices, we positioned ourselves within Collaborative Action Research (CAR). In our research group, Aurelia, Sandra and Anahí were the teachers, and Darío was both a teacher and the researcher who facilitated the CAR-CLIL project outlined in this paper.

With the purpose of sharing our experience with a wider audience, we asked ourselves:

a. In what ways do teachers benefit from involvement in Action Research (AR) for the integration of content and language?

b. To what extent does professional development through AR impact on student motivation to learn English?

In this report, we have decided to share the evaluation stages of the three cycles we developed so as to encourage other teachers and teacher-researchers to adopt CAR as a fruitful approach to improve and, perhaps, challenge their own practices. Each of the following sections is based on Darío' thesis in progress but we have added other aspects and data as we then looked back at the whole process once the CAR-CLIL project had come to an end. In addition, we have decided to leave our real names and original language, Spanish, in the data excerpts below so as to strengthen contextualisation and co-authorship of the knowledge generated.

\section{Content and Language Integrated Learning (CLIL)}

CLIL is often defined as an umbrella term or approach with a dual purpose in ELT: content learning and language learning (Costa and D’Angelo 2011; Coyle, Hood, and Marsh 2010; Haataja 2007). CLIL is seen as an innovation (Kiely 2011) since focus on meaning is 
firmly based on school content and therefore cognitive engagement, language learning, and motivation appear to be higher (Dale and Tanner 2012; Lasagabaster 2011; McCall 2012).

In theory, CLIL entails that content and language are interwoven 'without an implied preference for either' (Coyle 2007, 545). CLIL is an approach in which various methodologies are used to achieve a dual-focused form of instruction in language and content. This is usually rooted in Sociocultural Theory (Lantolf 2000) and therefore collaborative learning and scaffolding tools, such as teacher talk or context-responsive materials, are essential in the classroom.

Nevertheless, practice shows that there are various CLIL models and therefore this dual focus is not always equal or beneficial (Bruton 2011). These models may be placed along a continuum which goes from content-driven models to language-driven models (Coyle, Hood, and Marsh 2010). The former place an emphasis on content, for example bilingual education, since school subjects are taught in a foreign language usually by the subject teacher. In turn, language-driven models place an emphasis on language learning, particularly on language skills and vocabulary. Curricular content is used as a vehicle for language development and lessons are still in the hands of EFL teachers. Language-driven models may include systematic topic-based lessons, project work, and cross-curricular lessons (Coyle, Hood, and Marsh 2010; Lorenzo, Casal, and Moore 2010; Navés 2009).

\section{Collaborative Action Research}

What drove us to opt for action research? In Burns' $(2010,2)$ view, 'AR involves taking a self-reflective, critical, and systematic approach to exploring your own teaching contexts' so as to become effective teachers. The benefits of CAR could be multiplied and act as powerful instances of teacher development (Burns 2010, 2011) when teachers identify an issue and explore it in collaboration.

Locke and Riley (2009, 493) state that CAR could 'enhance teacher professionalism' as there will be reflection, knowledge generation, continuing development, and collaboration (Kiely and Davis 2010; Koshy 2010; Somekh, 2010). 
Tasker, Johnson, and Davies (2010) emphasise that staff meetings could engage teachers in reflective thinking and further personal understanding by talking with colleagues. CAR is crucial as teachers are not only 'the best people to carry out research on their own practices' (van Lier, 1994: 31) but also the vital agents of change in any educational policies to be implemented regardless of their scale. The changes initiated by teachers may start with a socio-constructivist approach which affects their local context but then extend to other domains thus becoming a socio-political approach which may underpin the renewal of educational systems (Burns, 2005).

In CAR, collaboration may occur when (1) teachers work together, and (2) when teachers work together with researchers. Through these modes of collaboration, CAR aims at narrowing the gap between teachers based in schools and researchers (Bruce, Flynn, and Stagg-Peterson 2011, 433-434; Torres Jaramillo and Monguí Sánchez 2008). These patterns of collaboration may not be the result of horizontal democratic undertakings since there could be different aims and gains especially when one of the teachers acts also as a teacher-researcher. However, what is important is that personal interests are acknowledged (Jones and Stanley 2010). Before starting, we understood that we all had invested interests. While all of us hoped to grow professionally and generate co-constructed knowledge for and from the classroom (Borg 2010; Lopez-Pastor, Monjes, and Manrique 2011; van Lier 1994), only Darío would obtain a doctorate degree.

Through CAR we aimed to surpass the idea of what we shall call industrialised teacher effectiveness. Our feeling is that industrialised teacher effectiveness may be seen as the ability of foreign language teachers to reproduce approaches concocted elsewhere. The more teachers apply an imposed or advertised approach, the more effective they will be. Instead, we see teacher professionalisation as a zone of convergence from which contextresponsive pedagogies emerge and irradiate classrooms through practice and knowledge coconstructed by teachers. 


\section{The CAR-CLIL project}

The Argentinian school year begins in March and finishes in early December with a twoweek winter break in July. English as a foreign language is taught two hours a week and our students stay in the same class during the whole year.

Based on Burns (2010), Darío designed the three CAR-CLIL cycles below (Figure 1) which were negotiated with the other teachers and the school principal. We implemented our CAR-CLIL project in 2011 and it involved three different classes at a secondary school which represented around 90 students. Through these three cycles we sought to follow a participatory process for educational change (Wedell 2009).

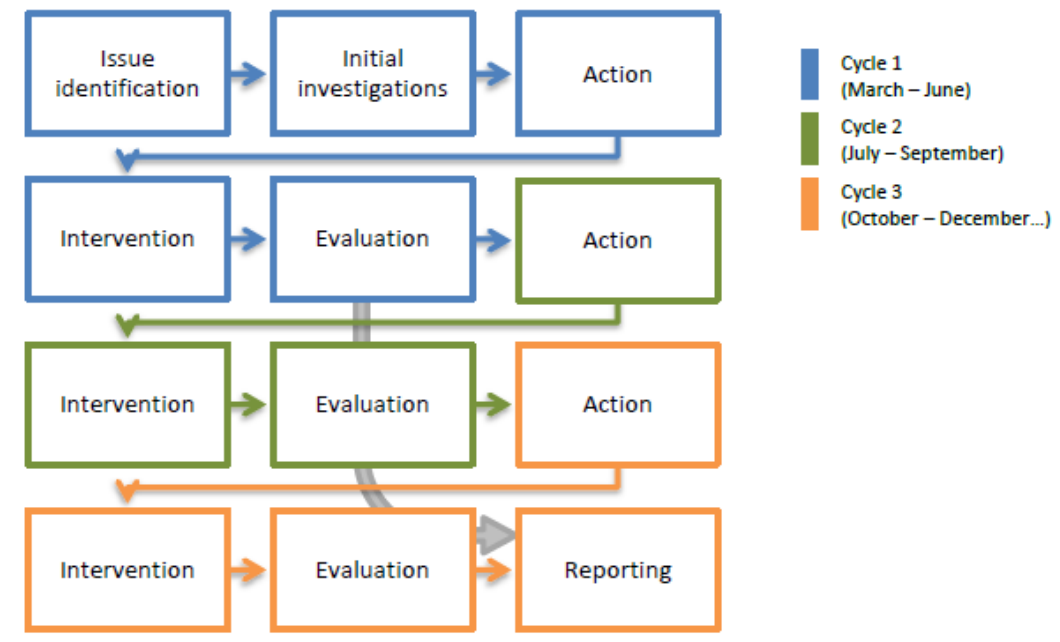

Figure 1: The CAR-CLIL cycles

Cycle 1 consisted of five facets. Our main aims were to refine the issues we sought to address, revisit and discuss our own beliefs about teaching through group interviews and classroom observation, and engage in exploratory classroom CLIL practices. In addition we were eager to collect our students' feedback and reflect on our own feelings through interviews and surveys (Evaluation). In order to improve our lessons following the constructive feedback obtained from our students and our motivation, we embarked on Cycle 2 in which we developed and explored more sophisticated CLIL lessons. The 
Evaluation facet of Cycle 2 provided us with new insights. At the same time our students expected us to continue exploring CLIL. Therefore Cycle 3 was set in motion until the end of the school year. This article is part of the Reporting facet of the project. This facet also included presentations at national and international conferences. Further details of each Cycle will be provided in the sections below.

Concerning data collection and instruments we aimed at integrating qualitative and quantitative methods (Burns 2010; Richards 2003) in order to obtain a richer account of the CAR-CLIL project. Data were collected through recorded meetings, group and individual interviews, classroom observations, field notes, and student questionnaires. Following Kvale and Brinkmann's (2009, 61-80) ethical recommendations, we obtained written permission from students and their parents to audio record the lessons and interview them. Meetings, interviews and questionnaires were carried out in Spanish.

Audio-recorded classroom observations took place in the Initial Investigations and the three Intervention facets. We agreed that Darío, as the teacher-researcher, would observe the other three teachers' language-driven CLIL lessons and that Anahí and Aurelia would observe his. For classroom observation, Darío developed a proforma for field notes which once completed served as a trigger for post-observation interviews which were also audio-recorded. Group interviews were regarded as active and transformative coconstructed accounts for the production of knowledge (Holstein and Gubrium 2003; Parker and Tritter 2006; Roulston 2010). Meetings were also audio-recorded and transcribed by Darío. These transcriptions were thematically analysed through inductive coding paying attention to common patterns, recurrent themes and words, and elaboration of thematic categories and networks (Attride-Stirling 2001; Braun and Clarke 2006). Darío also interviewed the three classes separately before developing questionnaires aimed at lesson evaluation. The questionnaires were first piloted and then completed by the students.

In this report (Reporting facet, Cycle 3), we have decided to share the Evaluation facet of each cycle (see grey arrow in Figure 1) so as to encourage other teachers and teacher-researchers in foreign language teaching to develop their own CAR-CLIL projects to challenge and improve their own practices. Each of the following sections is based on 
Darío' thesis in progress but we have added other aspects and data as we looked back at the whole process once the CAR-CLIL project had come to an end. In addition, we have decided to leave our real names and original language, Spanish, in the data excerpts below to strengthen contextualisation and co-authorship of the knowledge generated.

\section{Cycle 1: from Initial Investigations to Intervention}

Cycle 1 spanned from March until June 2011. It comprised five facets and was the longest cycle for we were all novice teachers investigating our own practices and developing CLIL as a team. In this cycle we went through five facets: Issue Identification, Initial Investigations, Action, Intervention, and Evaluation.

As regards the Issue Identification facet, we sought to become aware of our internal theories and beliefs (Johnson and Golombek 2011; Wyatt 2011a) and refine the issues to investigate through group interviews. We agreed that (1) our main aim was to promote speaking skills, (2) there was a clash between our motivation and that of our students', and (3) the coursebooks adopted were obstacles rather than tools. In our group meetings we focused on this third issue. After reading about materials development and evaluation (Harwood 2010; Tomlinson 2003, 2008) we concluded that the coursebooks presented two major weaknesses: topics were not context-responsive and activities only promoted lowerorder thinking skills.

In the Initial Investigations facet, we carried out a total of nine classroom observations as explained above with the aim of examining how we used those coursebooks. These were followed by post-observation interviews and class interviews with the students of each class. Both our students and we felt that lessons were demotivating because the coursebook did not match the students' language proficiency and cognitive development. Furthermore, we all felt that topics were the main driver underlying language learning and therefore these could be negotiated between students and teachers. As a consequence, we decided to develop our own materials. For this, we asked our students to suggest (1) topics related to the school curriculum, (2) sources of input, and (3) activities. In general, the topics were related to History, such as Nazis in Argentina. Students' most 
suggested sources were authentic audio-visual input, such as documentaries, film trailers, or TV interviews, and activities which promoted listening and speaking skills.

Based on those suggestions, we planned our lessons and materials during the Action facet. This extended over a month as it was difficult for us to work together given time constraints and finding suitable sources which offered the students new content (Coyle, Hood, and Marsh 2010). In the end, we decided to develop our materials individually and meet weekly for peer feedback. In those meetings we agreed that lesson planning and materials development were powerful triggers for reflection, motivation alignment, and teacher development as suggested in Tomlinson (2008). Regarding Intervention, each of us implemented these lessons, which were also observed, in June and after them we carried out new group interviews, class interviews, and student questionnaires (Evaluation).

\section{Cycle 1: Evaluation facet}

First, we examined the results of the students' questionnaires and the class interviews. The students perceived us as motivated teachers when we shifted from the coursebook to our own materials and centred our attention on learning language through content, i.e. CLIL. The students felt that our motivation increased theirs and they appreciated our requests for topics and materials which were authentic, i.e. with no pedagogical modifications (Gilmore 2007), and promoted listening and speaking skills. Overall, they felt that we had become more participatory, engaged in the lesson, and professional. In a class interview, a student said:

Student: $\quad$ Y hace al maestro mucho más participativo porque si no agarra el libro, te dice lo que hay que hacer y cada uno con su libro. [And that (teacher-developed materials) makes the teacher much more participatory because otherwise she just grabs the book, she tells you what to do and each of us does it individually.]

(Excerpt 1, Cycle 1)

Nonetheless, students then demanded that standards be raised as they felt capable of solving more complex activities (see Tomlinson 2008). They added that they could be 
further motivated if we developed materials which encouraged grammar and vocabulary practice and skills development through appealing and challenging topics, sources and activities.

We discussed the need to increase the number of authentic audio-visual materials and listening and speaking opportunities. However, other students still demanded grammar learning. When we re-read the transcript of this interview we realised that our main concerns were linked to our classroom performances and how to understand our students' feedback:

Darío: Entonces ustedes qué dicen de hacer diferente según lo que salga en las encuestas. Al menos en los míos les voy a tener que meter más gramática. [So you what do you guys say we should do differently according to the surveys? In my case, I'll have to do more grammar.]

Sandra: Sí, a estos también, listening y videos también y algún ejercicio gramatical, pero tampoco mucho porque sino se van a quejar. [Yes, me too, listening and videos also and some grammar exercises, but not too much either because then they'll complain.]

Anahí: Claro. [Sure.]

Sandra: Sí, lo que pasa es que también tenés que ver de acuerdo al material que tenés. Tampoco les vas hacer practicar conditional sentences o qué se yo si en el tema que tienen no está. [Yes, the thing is that you have to make do according to the material you have. You're not going to make them practise conditional sentences or whatever if the topic doesn't feature them.]

(Excerpt 2, Cycle 1)

The meetings also helped us reflect about the benefits and dynamics of collaboration. We all felt that CAR and materials development were beneficial to share and exchange ideas, activities and sources:

Darío: ¿Quieren que nos sigamos juntando? [Shall we carry on meeting?]

Anahí: $\quad$ Yo no tengo problemas en venir. Está bueno como para traer ideas y definir entre todos. [I have no problem with coming. It's good so that we bring ideas and decide among us three.]

Sandra: Traer cosas y ver acá entre los tres. [Bring things and decide among the three.] 
When looking back at Cycle 1, we agreed that the Action facet had acted as a compass which showed us how we perceived planning and what principles we followed for collecting and selecting sources, and developing our own activities. In addition, we saw CAR as a space for professional development (Locke and Riley 2009; Wyatt 2011a, 2011b) for it helped us work collaboratively on a common framework with shared aims even though each of us had different perceptions and motivations (Excerpt 3). While Darío noticed that action for change was the driving force during the Cycle 1, our last meetings also revealed that there was reflection on/in action as each stage unfolded. However, this reflective process was a loop between our individualities and us as a team. Even when we separately engaged in intra-reflections, these led to verbalised inter-reflections which would feed in the former (Johnson and Golombek 2011). We shared our thoughts, we disclosed our perceived threats and issues (Excerpt 2) and this level of honesty helped us not only improve the Intervention facet but also envisage a more successful Cycle 2 following our students' feedback and our own perceptions.

\section{Cycle 2: Action and Intervention facets}

In the Evaluation facet of Cycle 1 apart from providing feedback about our teaching performance, we asked our students to vote for new topics. The topics came from the school curriculum and we negotiated them as we pointed out that the topics had to be motivating for us too and within our range of knowledge. This time the most voted topics were related to History and Health Sciences.

The students also suggested new sources of input and activities. These indicated their interest in authentic input and activities which promoted collaborative work (Coyle, Hood, and Marsh 2010), higher-order thinking skills such as discussing or creating (Mehisto, Marsh, and Frigols 2008), and listening and speaking opportunities.

Cycle 2 took place between July (after the winter break) and September. Similarly to Cycle 1, we developed our materials individually during the Action facet and met to exchange opinions. Based on the feedback obtained, we first agreed on using authentic audio-visual sources, developing grammar noticing activities (Pica 2002), and making sure 
that activities were cognitively sequenced so that the intersection of language and cognitive demands derived from content could be fruitful (Kong and Hoare 2011).

The lessons and materials we developed were implemented between August and September. Classroom observations and post-observation interviews took place as in Cycle 1 so as to systematise data collection and reflect on our context-responsive practices. The

Intervention facet was followed by the Evaluation facet which also included group interviews with teachers and students and student questionnaires. However, we should mention that as we teachers became aware of the dynamic relationship between student motivation and teacher motivation and autonomy (Dörnyei and Ushioda 2011), we started Cycle 3 almost in parallel with the Evaluation facet of Cycle 2.

\section{Cycle 2: Evaluation facet}

When we reached the evaluation stage of Cycle 2, Darío understood that this stage had reflected a democratic process for lesson planning and materials development (McGrath 2002), and that every facet of it could be called a horizontal space for professional development. Although we acknowledged that each of us had entered this stage with different ideas and motivations, we finally agreed that we had grown at the same pace and that our doubts, concerns and observed possibilities were similar. In this space, Darío had become a facilitator who offered input on CLIL materials development when we met to share our materials in the belief that spaces had to be created to generate a dialogue between research, external/internal theories and praxis for the co-construction of knowledge through CAR (Goodnough 2010; Somekh and Zeichner 2009).

By Cycle 2 we had reconfigured our roles. For example, Darío felt in a better position to provide feedback to the rest of the collaborative group. But this role of 'feedback provider' had started to be shared thus reaching a stage of inter-teacher feedback. We then believed that any of us could seek and offer advice since our systematisation of collaborative work had also allowed us to strengthen interpersonal relationships. As an example, Aurelia once showed us her worksheet and explained her aims with every activity. After that, she added: 
Aurelia: ¿Les parece poco, mucho? [Do you think it's little, a lot?]

Darío: Lo que pasa que eso es personal. [The thing is that it's personal.]

Sandra: El tema es que tenés el tiempo acotado. [The issue is that you don't have much time.]

(Excerpt 4, Cycle 2)

In retrospect we understood that one aspect which had emerged strongly was our ability to share our reflections in action through talk (Moate 2010). For example, during the first meeting, Darío explained his new set of materials in comparison to Cycle 1:

Darío: A mí me toca hacer la clase sobre drogas. Bueno, yo tenía la tendencia a usar todo reading. A ver, cómo hice yo personalmente estos ejercicios, tenía esto (Year 1 survey results) a mano permanentemente. Entonces yo me decía, no, ellos quieren listening. Igual puse un ejercicio de reading y les metí algo de debate que me pedían para speaking. [I need to develop a lesson about drugs. OK, I had the tendency to do Reading. I mean, how I personally developed these exercises, I had this (Year 1 survey results) at hand all the time. So, I would tell myself, no, they want listening. Still I designed a reading exercise and I included a debate they wanted for speaking.]

(Excerpt 5, Cycle 2)

As Excerpt 6 below may show, teacher reflection was also generated through interviews. In this sense, we lived the transformative power of interviews and how reflections were triggered by our interactions (Matthew and Ross 2010). The interviews acted as a safe net to evaluate our own professional practices (Bruce, Flynn, and StaggPeterson 2011). We realised how our practices had started to improve through the CARCLIL project. For instance, Aurelia once said after an interview with Darío:

Aurelia: Pensé en las preguntas que me habías hecho ayer y como que después hice una reflexión de la clase, y bueno, por eso también modifiqué en cierta forma lo que tenía planificado para darles más lugar a ellos y controlar mi teacher talking time y darles lugar a ellos. [I thought about the questions you asked me yesterday and like then I reflected about the lesson, and well, that's why I also modified in a way what I had planned to give them more space and control my teacher talking time and give them more space to them.]

(Excerpt 6, Cycle 2) 
The interview, as a research instrument and a speech event, helped Aurelia revisit her own practices and, for example, reconsider the distribution of teacher-talking time and student-talking time. This same situation later helped Darío develop his own reflections. It was not the interview in isolation which acted as a reflection trigger and professional development opportunity. It was the interview inscribed in the systematic study of our own enquiries through CAR (Burns 2010).

Similarly, we all felt that our styles had changed. Our lessons in Cycle 2 had grown stronger based on our students' interests, needs, and feedback (Excerpt 5). Our change in practices due to the CAR-CLIL project started to be further acknowledged by the students who felt that their motivation and language proficiency had improved:

Student A: Como que el tema estaba bueno y los materiales eran tuyos. Entonces como que nos daban más ganas de escuchar y comentar. [Like the topic was interesting and the materials were yours. So, like we felt more interested in listening and commenting.]

Student B: Claro, además hicimos mucho de oral y listening y eso me parece que nos re sirvió. Y todo el vocabulario también de las drogas y el cuerpo. [Yes, besides we did a lot of oral work and listening and that I think was really helpful. And all the vocabulary also about drugs and the body.]

Student C: $\quad$ Igual, me parece que faltó más contenido, más tema. [Still, I feel like more content was needed.]

(Excerpt 7, Cycle 2)

Student C's comment about the apparent lack of content was also perceived by other students in the project. This may show that we failed to promote higher-order thinking skills through content and activity complexity. On the other hand, some students suggested using an international coursebook for grammar learning and teachers' materials for the CLIL characterised by meaningful topics and listening and speaking opportunities based on authentic sources of input. This also showed that our attempt to introduce grammar practice had failed. Therefore, the view that coursebooks and teacher-materials could be integrated emerged (McGrath 2002).

Overall, we all agreed that during Cycle 2 we had felt more comfortable and flexible as regards topics, lesson planning and materials development. In general terms, each of us developed lessons with fewer exercises in our worksheets. Furthermore, we also decided to 
extend the number of lessons during the Intervention facet so as to explore other possibilities depending on classroom dynamics. Because we were working with our students' feedback and had internalised our aims and procedures, the topic of motivation did not emerge. This made us reflect about the importance of aligning our motivations and needs through negotiation with our students and how the overall CAR-CLIL project was developing us professionally.

At the beginning of this report, we explained that our CAR-CLIL project consisted of three cycles. Initially, it was conceived as a two-cycle project but when we all saw the benefits it brought to our students and us, the idea of a third cycle emerged:

\footnotetext{
Sandra: ¿Y podemos hacer otro ciclo? [And can we do another cycle?]

Darío: Dale. [Sure.]

Sandra: Yo ya estuve ahora con noveno haciendo lo de basketball. Espectular nene cómo trabajaron esos pibes. [I've been doing basketball with year 9. It's amazing how those kids worked.]

Darío: Son cosas que antes no se nos hubieran ocurrido ni en pedo. Bueno, vos no tomás. [These are things that would have never hit us even if drunk. Well, you don't drink.]

Sandra: Es genial y ahora estoy arrancando con la computadora. Las clases que hago para el instituto, ahora, a ver. ¡You've CLILed me! [It's great and now that I'm starting with the computer. The lessons I plan for the language school, I mean. You've CLILed me!]
}

(Excerpt 8, Cycle 2)

It was at this stage that our explorations were beyond Darío' control as a teacherresearcher. In the case of Sandra, she achieved full autonomy for she had started to introduce CLIL in her language school lessons and with other classes at our school.

All in all, we felt that we had developed through collaboration. Darío suggested the phrase teacher development in collaboration to mean the benefits of our systematic meetings to evaluate coursebooks, share own beliefs and concerns about our role, our students, and our expectations. In Cycle 1 we needed to work collaboratively to ensure the success of our first explorations. However, in Cycle 2 we felt that we wanted to work together as we observed the benefits of this type of work. 
Collaborative work helped us become more autonomous not only among ourselves but also autonomous in the sense that we grew less coursebook and paper-based materials dependent (Tomlinson 2008; Wyatt 2011b). The teacher autonomy we had developed led to the reconfiguration of our identities in relation to power (Clarke 2009) for we all felt that our personal identities had been internally and externally accepted by our peers. In a nutshell, we conceived teacher identity as the process of becoming a teacher. colleagues, students and other members of the community grant teachers their identity as such when they recognize their constant professional development (Clarke, 2008, 2009; Norton and Toohey, 2011).

Our development as teachers was not only tied to working with colleagues but also to the reflective discovery of our own potentials, interests and control of our own behaviours. In sum, teacher reflection, motivation, and autonomy constituted the rationale of Cycle 3.

\section{Cycle 3: Action and Intervention facets}

The Action, Intervention, and Evaluation facets were covered between October and December 2011. We developed new lessons and materials taking into account the new curriculum-related topics, sources, and more demanding activities suggested by our students. The materials maintained a focus on listening and speaking skills through authentic sources. However, we developed activities for evaluating sources, critiquing arguments, and developing positions on topics such as drug decriminalisation. In addition to our own materials, we decided to return to the coursebook so that grammar was also taught as we had traditionally done.

During the Intervention facet, each of us taught three lessons. Research procedures

were similar to Cycles 1 and 2. Nevertheless, the Evaluation facet was shorter since all of us were committed to end-of-year school activities, reports, and exams. We opted for a final group meeting with us four, and class interviews and questionnaires.

\section{Cycle 3: Evaluation facet}


In general, the students evaluated the overall project under a positive light particularly in relation to language improvement and motivation. Both the interviews and questionnaires revealed that language and to a lesser extent content had been developed through our language-driven CLIL lessons.

Students' awareness of their own language improvement and change in motivation emerged through personal experiences:

Student A: Vocabulario aprendí un montón. Además me di cuenta que si me interesa puedo hablar de corrido. Siempre pensé que o sea vos me hablabas y te entendía pero después tenía que estar una hora pensando para responderte. Me di cuenta que en realidad como que si lo pienso, me sale solo, pero no me había dado cuenta de eso yo. [I learnt a lot of vocabulary. Besides I realised that if I'm interested I can speak fluently. I always thought that, I mean, like you talked to me and I could understand but then I had to spend an hour thinking to answer. I realised that in $(\ldots)$ fact like if I think about it, things come out naturally, but I hadn't noticed that.]

Student B: Por lo menos hablamos algo. Aparte, todos los grupos pudieron hablar más y estábamos interesados. Fue todo un éxito. [At least we talked a little. Besides, all the groups could speak more and we were more interested. It was a success.]

(Excerpt 9, Cycle 3)

Most students realised their increasing motivation as they perceived two aspects of motivated behaviours: participation and attention (Huang 2011). As Student B in excerpt 9 indicated, all the groups could speak more (participation) and everyone was interested in listening to them (attention).

Having our students' final reflections, Darío arranged a meeting. The first part of it was concerned with CLIL pedagogies and how our practices had been informed by the literature (Coyle, Hood, and Marsh 2010; Mehisto, Marsh, and Frigols 2008) and our own reflections. We felt that we had co-constructed new knowledge for and from our classrooms, which is one of the aims of CAR and context-responsive CLIL pedagogies (Dalton-Puffer 2011; Wolff 2010).

The second part centred on evaluating the impact of the CAR-CLIL project on our professional development individually and as a team. For example, Sandra discovered that 
her identity as a more capable and autonomous teacher had been reconfigured as a consequence of self-discovery and awareness of her teaching practices (Goodnough 2010; Johnson and Golombek 2011). She found out that she was capable of using resources such as YouTube videos, notebooks, and data projectors. Most importantly, she discovered teaching content through English was a powerful drive in her development:

Sandra: Lo que he descubierto es que en realidad lo que a mí me gusta es enseñar a través del inglés. Yo disfruto preparando cualquier cosa no sé capaz que de Canada, pero enseñar otras cosas usando el inglés. Y también me doy cuenta que utilizando eso vos después que lo vas preparando ves en el material que vos tenés 'ah! Mirá acá tengo un past simple o aha conditional sentences. Bien, entonces, entrás a agarrar la gramática pero después de lo otro. [What I've discovered is that in fact what I like is teaching through English. I enjoy preparing anything, maybe about Canada, but teaching other things using English. And I've also realised that you as you prepare the material you have you notice simple past or conditional sentences. So you take grammar from another angle.]

(Excerpt 10, Cycle 3)

We shared Maria's feelings since we discovered our interest in teaching content through the medium of English. In addition, we also realised how aware we had become through the process of developing our own materials from collecting and selecting sources to producing lesson plans which could include grammar noticing activities.

While Maria had provided an overarching answer to explain her professional development (Excerpt 10), both Aurelia and Anahí remarked that their students' feedback had been a real asset. Aurelia added that the opportunity of developing her own materials had enhanced and affirmed her teacher autonomy and identity in the sense that she did not see herself as a passive consumer of marketed coursebooks:

Aurelia: El hecho de poder tener el feedback de ellos te hace repensar la forma en que confeccionás el material. Por lo general el profe de Inglés es el libro. [The fact of having their feedback makes you rethink the way you develop materials. In general the teacher of English is the coursebook.]

(Excerpt 11, Cycle 3) 
Aurelia's last comment revealed that teachers may be seen as coursebook deliverers, a view which had also emerged from the students' feedback. In other words, the role of the teacher was to follow a coursebook strictly. In that sense, Darío understood that teacher-developed materials could promote the professional development of resourceful, active and autonomous teachers. Darío experienced the same feelings. As he was going from one cycle to the next, he also noticed how autonomous he had become and how his students' feedback together with Aurelia's classroom observation notes had helped him become aware of his own teaching strategies. For example, in the past he used to plan lessons heavily based on worksheets overloaded with activities. After the students' and teachers' feedback he received he learnt to be more selective and allow himself more classroom time to exploit other possibilities.

We also valued the impact of collaborative work through peer observation. Sandra valued the possibility of having Darío in her classroom. Similarly, Aurelia, Anahí and Darío highlighted the benefits of observing and being observed:

Aurelia: Yo creo que se aprende mucho más porque en realidad si uno trabaja aislado no es lo mismo el ser autocrítico. [I think that you learn a lot more because, in fact, if you work isolated, it isn't the same as a self-critique .]

Sandra: No. [No.]

Aurelia: Además, al verte también veía otras ideas que funcionaban con vos. Es como que vas tomando ideas de otras personas. [Besides, by observing you I saw other ideas that worked with you. It was like you were taking ideas from other people.]

Anahí: Sí, enriquece. [Yes, it's enriching.]

Darío: $\quad$ Y sí, tengo altos mecanismos de autodefensa como diciendo si no les gustó no es por mí. Aurelia me ayudó a tener otra mirada quizás más objetiva. [True, I have complex self-defence mechanisms like saying if they didn't like it, it wasn't my fault. Aurelia's feedback helped me have another perhaps more objective view.]

(Excerpt 12, Cycle 3)

In relation to Excerpt 12, peer observation helped us, with different degrees of impact, become more reflective teachers since our own perceptions and self-evaluation mechanisms were confirmed or challenged by a colleague. In Darío' case, he always had his reservations about his students' feedback as it was extremely positive and showed very little scope for improvement. In addition, Darío noticed that Aurelia seemed to believe that 
apprenticeship of observation was an invaluable model for professional development. When we discussed this perception, we discovered that it rang true with all of us.

Cycle 3 and the overall results of our CAR-CLIL project prompted the need to continue working collaboratively even when our meetings meant working more hours. Collaborative work was motivating since we could construct new experiences as well as learning and knowledge socially constructed. In this respect, Sandra added that systematic meetings were necessary:

Sandra: Uno tiende a no sistematizarse en eso, pero es necesario. Una vez cada tanto lo tenés que hacer porque es como una inyección, te dan más pilas. [One tends not to systematise this (meetings), but it's necessary. Now and then you have to do it because it's like an injection of energy.]

Anahí: Sí, es super productivo para intercambiar ideas. [Yes, it's super productive to exchange ideas.]

Aurelia: Yo vengo de una escuela que no tenía con quién hablar. Con nadie. Me encanta poder compartir. [I come from a school where I had no one to talk with. Nobody. I love being able to share.]

(Excerpt 13, Cycle 3)

The CAR-CLIL project was an opportunity to meet and work towards a common goal for one academic year (Excerpts 11-13). We developed professionally by reaping the benefits of integrating content and language, developing our own materials autonomously, and by growing with others, our colleagues and our students through their feedback and regular meetings. We felt that not only had principles for CLIL materials development emerged, but our professional practice had become embedded in a complex construct constituted by increased autonomy, enhanced motivation, and a change of identity that shaped the way we had engaged in context-responsive pedagogies.

\section{Revisiting the benefits}

CAR features and its transformative power (Rainey 2011, van Lier 1994) emerged robustly since our teachers-in-collaboration enterprise was rooted in a positive and motivating working atmosphere (López-Pastor, Monjes, and Manrique 2011), as our interactions above 
revealed (eg. Excerpt 8). In addition, we reached different points of self-regulation (Lantolf 2000) in regards to managing our own language-driven CLIL implementations. This process was also encouraged by classroom observations and students' feedback (Excerpt 1). This may confirm the reflexive effect that observations may have in qualitative research. We believed that we became more autonomous as a result of systematic observations and meetings. (Excerpt 12).

While we developed professionally as a team, each of us seemed to have experienced different degrees of personal development in different domains. For example, Aurelia experienced the transformative power of interviews (Matthew and Ross 2010) as Excerpt 6 shows. Sandra discovered that she could handle technology and that she enjoyed teaching content through language (Excerpt 9). She felt she had changed her approach to teaching as she began to extend her CLIL experiences to other domains of her practice when she internalised the concept of CLIL (Excerpt 8), thus moving from externalisation to verbalisation of concepts (Johnson and Golombek 2011).

In their identity as teachers, Darío and Anahí learnt to share their beliefs and concerns. As a researcher, Darío noticed deeper levels of reflection and understanding and flexibility about his decisions, data collection instruments, their impact, and data analysis. He learnt to accommodate himself to these changes and value the possibilities they could offer. He felt that the CAR-CLIL project helped transform teacher identities and produce knowledge from the classroom so that teaching and learning practices could be negotiated and enhanced.

The CAR-CLIL project gave us the opportunity to renew the EFL curriculum at an institutional level (Burns 2005; Altrichter and Posch 2009) as we teachers identified ourselves as reflective-reflexive creators of knowledge from/for our context (Borg 2010; Goodnough 2010). When these explorations were perceived as successful, we felt motivated to teach and this motivation impacted on our students. They felt motivated to learn and their language learning improved not only because of our motivation but also because of the integration of content and language and the negotiation of topics, sources, and activities. Nevertheless, their feedback and interest in a combination of materials and a focus on grammar posed new challenges for future actions. 


\section{Conclusion}

Although the experience was time consuming and required coordinated efforts, we developed professionally. We co-constructed new knowledge and changed the way EFL could be taught. Our enhanced motivation and autonomy drove us to build a teacher identity mainly characterised by the ability to introduce changes in the curriculum through informed and democratic decisions which were truly context-responsive. Our professional development impacted positively on our learners as their motivation to learn English increased.

We hope that our explorations may help other MFL teachers to explore CLIL through CAR bearing in mind that the process demands time, extra effort, and the democratisation of our classroom practices. This may entail that we open up professionally and create an honest and positive relationship particularly when CAR involves classroom observations, feedback from peers and students, and systematic interviews about our internal theories. However, it is through these research strategies and negotiated practices that teacher motivation and autonomy, student motivation, and language learning are improved and socially reconfigured in a way that is essentially democratic.

\section{References}

Altrichter, H. and P. Posch. 2009. Action Research, Professional Development and Systemic Reform. In The SAGE Handbook of Educational Action Research, ed. S. Noffke and B. Somekh, 213-225 .London: Sage.

Attride-Stirling, J. 2001. Thematic Networks: an analytic tool for qualitative research. Qualitative Research 1, no. 3: 385-405.

Borg, S. 2010. Language teacher research engagement. Language Teaching 43, no. 4: 391429.

Braun, V. and V. Clarke. 2006. Using thematic analysis in psychology. Qualitative Research in Psychology 3, no. 2: 77-101.

Bruce, C.D., T. Flynn and S. Stagg-Peterson. 2011. Examining what we mean by collaboration in collaborative action research: a cross-case analysis. Educational Action Research 19, no. 4: 433-452.

Bruton, A. 2011. Is CLIL so beneficial, or just selective? Re-evaluating some of the research. System 39, no. 4: 523-532. 
Burns, A. 2005. Action research: an evolving paradigm? Language Teaching 38, no. 2: 5774.

Burns, A. 2010. Doing Action Research in English Language Teaching. A Guide for Practitioners. Abingdon: Routledge.

Burns, A. 2011. Action Research in the field of second language teaching and learning. In Handbook of Research in Second Language Teaching and Learning Vol. 2, ed. E. Hinkel, 237-253. New York: Routledge.

Clarke, M. 2008. Language teacher identities: Co-constructing discourse and community. Clevedon, UK: Multilingual Matters.

Clarke, M. 2009. The Ethico-politics of Teacher Identity. Educational Philosophy and Theory 41, no. 2: 185-200.

Costa, F. and L. D’Angelo. 2011. CLIL: A suit for all seasons?' Latin American Journal of Content \& Language Integrated Learning 4, no. 1: 1-13.

Coyle, D. 2007. Content and Language Integrated Learning: Towards a Connected Research Agenda for CLIL Pedagogies. International Journal of Bilingual Education and Bilingualism 10, no. 5: 543-562.

Coyle, D., P. Hood, and D. Marsh. 2010. CLIL Content and Language Integrated Learning. Cambridge: Cambridge University Press.

Dale, L. and R. Tanner. 2012. CLIL Activities. A resource for subject and language teachers. Cambridge: Cambridge University Press.

Dalton-Puffer, C. 2011. Content-and-language integrated learning: from practice to principle? Annual Review of Applied Linguistics 31, no. 1: 182-204.

Dörnyei, Z. and E. Ushioda. 2011. Teaching and Researching Motivation, $2^{\text {nd }}$ ed. Harlow: Pearson.

Gilmore, A. 2007. Authentic materials and authenticity in foreign language learning. Language Teaching 40, no. 2: 97-118.

Goodnough, K. 2010. The role of action research in transforming teacher identity: modes of belonging and ecological perspectives. Educational Action Research 18, no. 2: 167182.

Haataja, K. 2007. A definition of CLIL as an umbrella term: A historical perspective. In Good Practice in Content and Language Integrated Learning, ed. B. Roza González, 9. BeCLIL: Gijón.

Harwood, N. 2010. Issues in materials development and design. In English Language Teaching Materials. Theory and Practice, ed. N. Harwood, 3-30. Cambridge: Cambridge University Press.

Holstein, J.A. and J.F. Gubrium. 2003. Active interviewing. In Postmodern Interviewing, ed. J.F. Gubrium and J.A. Holstein, 67-80. Thousand Oaks, CA: Sage.

Huang, K. 2011. Motivating lessons: A classroom-oriented investigation of the effects of content-based instruction on EFL young learners' motivated behaviours and classroom verbal interaction. System 39, no. 2: 186-201.

Johnson, K. and P. Golombek. 2011. The transformative power of narrative in second language teacher education. TESOL Quarterly 45, no. 3: 486-509.

Jones, M. and G. Stanley. 2010. Collaborative action research: a democratic undertaking or a web of collusion and compliance? International Journal of Research \& Method in Education 33, no. 2: 151-163.

Kiely, R. 2011. Understanding CLIL as an innovation.' Studies in Second Language Learning and Teaching 1, no. 1: 153-171. 
Kiely, R. and M. Davis. 2010. From transmission to transformation: Teacher learning in English for speakers of other languages. Language Teaching Research 14, no. 3: 277295.

Kong, S. and P. Hoare. 2011. Cognitive content engagement in content-based language teaching. Language Teaching Research 15, no. 3: 307-324.

Koshy, V. 2010. Action Research for Improving Educational Practice. A step-by-step guide. $2^{\text {nd }}$ ed. London: Sage.

Kvale, S. and S. Brinkmann. 2009. InterViews. Learning from the Craft of Qualitative Research Interviewing. 2nd ed. London: Sage.

Lantolf, J. ed., 2000. Sociocultural Theory and Second Language Learning. Oxford: Oxford University Press.

Lasagabaster, D. 2011. English achievement and student motivation in CLIL and EFL settings. Innovation in Language Learning and Teaching 5, no. 1: 3-18.

Locke, T. and D. Riley. 2009. What happened to educational criticism? Engaging with a paradigm for observation. Educational Action Research 17, no. 4: 489-504.

López-Pastor, V.M., R. Monjas, and J.C. Manrique. 2011. Fifteen years of action research as professional development: seeking more collaborative, useful and democratic systems for teachers. Educational Action Research 19, no. 2: 153-170.

Lorenzo, F., S. Casal, and P. Moore. 2010. The Effects of Content and Language Integrated Learning in European Education: Key Findings from the Andalusian Bilingual Sections Evaluation Project. Applied Linguistics 31, no. 3: 418-442.

Matthews, B. and L. Ross. 2010. Research Methods. A practical guide for the social sciences. Harlow: Pearson.

McCall, I. 2012. Score in French: motivating boys with football in Key Stage 3. Language Learning Journal 39, no. 1: 5-18.

McGrath, I. 2002. Materials Evaluation and Design for Language Teaching. Edinburgh: Edinburgh University Press.

Mehisto, P., D. Marsh, and M. Frigols. 2008. Uncovering CLIL: Content and Language Integrated Learning in Bilingual and Multilingual Education. Oxford: Macmillan Publishers Ltd.

Moate, J. 2010. The Integrated Nature of CLIL: A Sociocultural Perspective. International CLIL Research Journal 1, no. 3: 38-45.

Navés, T. 2009. Effective Content and Language Integrated Learning (CLIL) Programmes. In Content and Language Integrated Learning. Evidence from Research in Europe, ed. Y. Ruiz de Zarobe and R.M. Jiménez Catalán, 22-40. Bristol: Multilingual Matters.

Norton, B. and K. Toohey. 2011. Identity, language learning, and social change. Language Teaching 44, no. 4: 412-446.

Parker, A. and J. Tritter. 2006. Focus group method and methodology: current practice and recent debate. International Journal of Research \& Method in Education 29, no. 1: 23-37.

Pica, T. 2002. Subject matter content: How does it assist the interactional and linguistic needs of classroom language learners? The Modern Language Journal 85, no. 1:119.

Rainey, I. 2011. Grassroots Action Research and the Greater Good. Profile 13, no. 1: 3154.

Richards, K. 2003. Qualitative Inquiry in TESOL. Basingstoke: Palgrave Macmillan. 
Roulston, K. 2010. Considering quality in qualitative interviewing. Qualitative Research 10, no. 2: 199-228.

Somekh, B. 2010. The Collaborative Research Network: 30 years of agency in developing educational action research. Educational Action Research 18, no .1: 103-121.

Somekh, B. and K. Zeichner. 2009. Action research for educational reform: Remodelling action research theories and practices in local contexts. Educational Action Research 17, no. 1: 5-21.

Tasker, T., K. Johnson, and T. Davis. 2010. A sociocultural analysis of teacher talk in inquiry-based professional development. Language Teaching Research 14, no. 2 : 129-140.

Tomlinson, B. 2003. Developing Principled Frameworks for Material Development. In Developing Materials for Language Teaching, ed. B. Tomlinson, 107-129. London/New York: Continuum.

Tomlinson, B. 2008. Language Acquisition and Language Learning Materials. In English Language Learning Materials. A Critical Review, ed. B. Tomlinson, 3-14. London/New York, NY: Continuum.

Torres Jaramillo, C. and Monguí Sánchez, R. 2008. Professional Development Schools: Establishing Alliances to Bridge the Gap between Universities and Schools. Profile 10, no. 1: 181-194.

van Lier, L. 1994. Action Research. Sintagma 6: 31-37.

Wedell, M. 2009. Planning for Educational Change. Putting people and their contexts first. London/New York: Continuum.

Wolff, D. 2010. Developing Curricula for CLIL: Issues and Problems. In Language Learner Autonomy. Policy, Curriculum, Classroom. A Festchrift in Honour of David Little, ed. B. O'Rourke and L. Carson, 103-120. Bern: Peter Lang.

Wyatt, M. 2011a. Teachers researching their own practice. ELT Journal 65, no. 4: 417-425.

Wyatt, M. 2011b. Becoming a Do-it-yourself Designer of English Language Teaching Materials. Forum Qualitative Sozialforschung / Forum: Qualitative Social Research 12, no. 1. At http://nbn-resolving.de/urn:nbn:de:0114-fqs1101334 